\title{
A New Blennoid Fish from Tyôsen ${ }^{(1)}$
}

\author{
Kiyomatsu MATSUBARA (formerly, SAKA MoTO)
}

While at the Tyôsen Fisheries Experimental Station at Huzan, in January 1932, my attention was drawn to a series of specimens of a blennoid fish, which were kindly placed at my disposal by Mr. Keitarô Uchida. They proved, when carefully examined at the Zoological Laboratory, Imperial Fisheries Institute, to represent a new species, a description of which is given in this paper with a key to all the hitherto known species of the genus Zoarchias to which the newly erected species belongs. It is with much pleasure that I dedicate it to the above-mentioned ichthyologist with the name, $Z$. Uchidai, n. sp. I wish herewith to appreciate my indebtedness to Dr. A. TERAO, under whose supervision the present study was carried out. I am also much obliged to Prof. Tamezô MonI of the Keizyô Imperial University and Asst. Prof. K. Ebina for help kindly rendered.

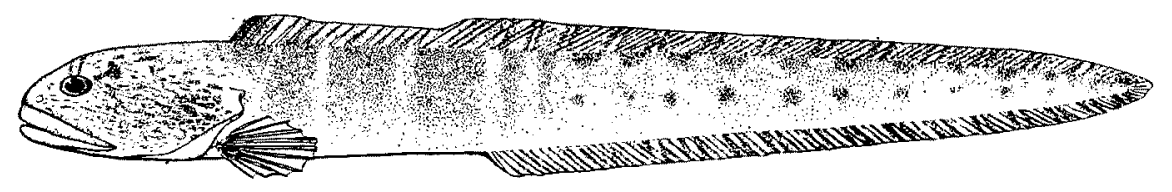

Fig. 1. Zoarchias uchidai, n. sp. $\delta \times \frac{1}{1}$

Zorrehias Uchidıi, n. sp.

(New Japanese name: Uchida-ito-ginpo)

Head $5 \frac{1}{20}$ in total length; depth $9 \frac{7}{10}$; eye $6 \frac{9}{10}$ in head; snout $4 \frac{4}{5}$; interorbital space $9 \frac{7}{10}$. D. XV, 78. A. I, 69 .

Body elongate, very much compressed, gradually tapering from head to the pointed tail. Head moderate, compressed and pointed; snout rather sharp; jaws subequal, the upper jaw slightly longer than the lower; eye high up, but its upper rim not above level of interorbital space; interorbital space convex; mouth very wide, slightly oblique, the cleft on lower side of head, parallel with ventral outline, the maxillary extending beyond orbit, its length slightly shorter than half the length of head; teeth pointed, in narrow bands on jaws, vomer and palatines; the anterior teeth larger than the lateral. Gill-membranes continuous, free from the isthmus, forming broad fold across it; gill-rakers on

(1) Contributions from the Zoological Laboratory, Imperial Fisheries Institute (Tôkyô), No. 27. 
first arch $3+10$, minute, slender and pointed; pseudobranchiae large. Head without filaments or papillae; nostrils with tubes, head naked, body with minute, circular, deeply-embedded scales; no lateral line.

Dorsal inserted above the base of pectoral, the spines strong and pungent, their anterior six spines rather long, equal or a little longer than the orbit, the following spines shorter than orbit, the membrane of dorsal spines very thick, somewhat thinner on soft dorsal; both the spines and rays entirely hidden; not incised between spines or rays; base of spinous part of fin occupying $\frac{1}{5}$ the length from origin of fin to tip of tail. Anal inserted immediately behind vent and beneath about the sixth soft ray of dorsal; the spine very strong, $1 \frac{1}{2}$ in height of rays which are longer than diameter of orbit; membrane of fin not incised. Dorsal and anal confluent with caudal, which is pointed. Pectoral rounded, $2 \frac{3}{10}$ in head. No ventrals.

Color in formalin gray, crossed with very faint, irregular, dusky bands; head densely spotted and reticulated with dark gray. Soft dorsal and anal with whitish vertical bands, each band being lined with blackish line on both sides, number of bands about 14 on soft dorsal and about 13 on anal; spinous dorsal dark gray, a black patch on anteriormost spines of dorsal; caudal whitish. Pectoral also whitish, with a blackish oblong patch at its base.

As given in the key appended to this paper, this species can be easily distinguished from $Z$. anguillaris, $Z$. glaber, $Z$. veneficus and $Z$. aculeatus by the smaller number of dorsal spines and the posterior insertion of anal, which begins under sixth soft dorsal (but not under the spinous dorsal as in the other four species). This species is allied to $Z$. neglectus Tanaka, but differs from it by the smaller eye, narrower interorbital space, smaller number of spinous dorsals and the posterior insertion of anal (anal being inserted beneath the origin of soft rays of dorsal in $Z$. neglectus).

Holotype is a male specimen, $\mathbf{1 2 2 . 3} \mathrm{mm}$ in total length from Huzantin, near Huzan, Tyôsen, collected by Mr. Keitarô UCHIDA, and preserved in the Zoological Laboratory, Imperial Fisheries Institute, Tokyo, No. 8. A large number of cotypes are deposited in the Tyôsen Fisheries Experimental Station at Huzan.

Key to the Species of Zoarchias.

a. Anal inserted beneath the spinous portion of dorsal

b. Anal with three spines.

c. Anal inserted beneath twenty-eighth dorsal spine; dorsal XXXIII, 45 ; and III, 38 (?): base of spinous dorsal nearly two-thirds as long as the fin; and spines stiff, the second stout, longest, twice as long as the diameter of eye, the first two close together, the third far 
separated from the former, the origin of soft anal ray nearly opposite to insertion of soft dorsal. ............ anguillaris Mori.

bb. Anal with one spine.

d. Anal inserted beneath about the twenty-second spine of dorsal; color in formalin brownish, without markings throughout, body slender, its depth $13 \frac{1}{8}$ in total length; dorsal XXXII, 86, anal I, 93 $\ldots \ldots \ldots \ldots \ldots \ldots \ldots . \ldots \ldots$ glabber Tanaka.

dd. Anal inserted below eighteenth spine of dorsal: color in spirits light brownish yellow, marked with dusky color, forming a sort of network with a row of circular openings about the size of pupil; depth of body 11 in total length; dorsal XXVIII. 77, anal J, 78.

.......... veneficus Jordan and Snyder.

ddd. Insertion of anal uncertain; body striped and spotted with black markings; dorsal XXXII ........... aculeatus (Basilewsky)

aa. Anal inserted beneath the soft portion of dorsal; anal with one spine

e. Anal inserted beneath origin of soft dorsal; eye rather large, $3 \frac{3}{5}$ in head; interorbital space broad 6; dorsal XXII, 65; anal I, 55. $\ldots \ldots \ldots \ldots \ldots \ldots \ldots$. neglectus Tanaka

ee. Anal inserted beneath sixth ray of soft dorsal; eye small, $6 \frac{9}{10}$ in head; interorbital space narrow $9 \frac{7}{10}$; dorsal XV, 78; anal I, 69. 